\title{
El uso del preservativo masculino reduce el riesgo de transmisión genital del virus del papiloma humano en mujeres jóvenes
}

Male condom use reduces human papiloma virus genital transmission risk in young female

Winer J y col. N Engl J Med. 2006;354(25):2645-54

\section{Objetivo}

Evaluar si el uso de preservativo masculino reduce el riesgo de transmisión sexual del virus del papiloma humano (HPV).

Diseño

Estudio longitudinal de cohorte.

\section{Lugar}

Universidad de Washington, Washington, EE.UU.

\section{Pacientes}

Fue seguida durante un promedio de 33,9 (+/- 11,8) meses una cohorte integrada por 82 mujeres de 18 a 22 años de edad, estudiantes de la Universidad de Washington que habían reportado su primera relación sexual vaginal durante el transcurso del estudio o durante las dos semanas previas de comenzado el seguimiento.

\section{Evaluación de factores de riesgo}

Número de relaciones sexuales vaginales, frecuencia de utilización del preservativo, condición de circuncisión de la pareja, reporte de nuevas parejas sexuales y de parejas previas de sus parejas. Las pacientes respondieron cada dos semanas cuestionarios electrónicos sobre su comportamiento sexual.

\section{Medición de resultados principales}

Cada cuatro meses fueron evaluadas la incidencia* de HPV y de citologias positivas para displasia o cambios compatibles con infección por HPV, realizándosele a las participantes un examen ginecológico con Papanicolau (PAP) y reacción de
PCR para HPV de muestras vulvovaginales y cervicales. Los resultados fueron ajustados por los factores de riesgo recabados.

\section{Resultados principales}

Fueron identificadas 126 nuevas infecciones por HPV (casos) en 40 mujeres luego de su primera relación sexual y 14 lesiones intraepiteliales escamosas (SIL). Luego de ajustar por los potenciales confundidores, el Hazard Ratio* (HR) de las que reportaron haber usado siempre el preservativo vs. quienes reportaron haberlo usado menos del $5 \%$ de las veces fue 0,3 (IC95\% 0,1 a 0,6). Ver tabla 1.

Tabla 1: incidencia de infección genital por el virus del papiloma humano (HPV) según el autorreporte de frecuencia de uso de preservativo masculino desde el inicio de las relaciones sexuales $(n=82)$.

\begin{tabular}{c|c}
$\begin{array}{c}\text { Porcentaje de las relaciones sexuales en las } \\
\text { que se reportó el uso de preservativo }\end{array}$ & $\begin{array}{c}\text { Riesgo de nueva infección por } \\
\text { el virus del papiloma humano }\end{array}$ \\
\begin{tabular}{c} 
Menos del $\mathbf{5 \%}$ (grupo tomado como referencia) \\
\hline $\mathbf{5}$ a $\mathbf{4 9 \%}$
\end{tabular} & 1,0 \\
\hline $\mathbf{5 0}$ a $\mathbf{9 9} \%$ & $1,0(0,5-1,8)$ \\
\hline $\mathbf{1 0 0} \%$ & $0,5(0,3-0,9)$ \\
\hline
\end{tabular}

\section{Conclusiones}

El uso consistente de preservativo por parte de sus parejas masculinas determina una reducción en el riesgo de infección genital por HPV en mujeres.

Palabras clave: utilización del condon, papiloma virus, parejas sexuales. Key words: condoms/utilization, papilomavirus infection, sexual partners. Fuente de financiamiento: National Institute of Allergy and Infectious Diseases.

\section{Comentario}

La evidencia actual demostraba que el predictor más consistente de infección genital por HPV es la actividad sexual y el número de parejas sexuales ${ }^{1}$ tanto del hombre como de la mujer, pero no era concluyente en demostrar si el preservativo reducía el riesgo de transmisión del $\mathrm{HPV}^{2}$, considerándose posible la transmisión manual por ejemplo durante el juego previo o en relaciones sexuales no vaginales.

Estudios como éste, que evaluó el comportamiento sexual y que requirió la realización de un examen ginecológico con toma de PAP cada cuatro meses, representan un gran desafío por su diseño, conllevando por otro lado un sesgo de selección ya que se inmiscuyen en temas íntimos y difíciles de ser abordados, más aún en adolescentes durante el comienzo de sus relaciones sexuales. En parte por estos motivos, se podría suponer que el número de pacientes que aceptó participar fue bajo $y$, por ende no se detectó la cantidad suficiente de displasias cervicales (SIL) para obtener resultados significativos.
Se plantea como interrogante si los resultados son extrapolables a otras poblaciones, es decir, si las jóvenes universitarias que acceden a participar en un estudio como éste son representativas de la población en riesgo de contraer HPV. Sin embargo, a pesar del posible sesgo de cortesía* que pudo haber ocurrido en esta encuesta y que podría sobrestimar el uso de preservativo, el uso de condón masculino apareció como muy protector -a pesar de que quizás fue menos usado que lo realmente reportado- lo que fortalece los resultados de esta investigación.

\section{Conclusiones de la comentadora}

Se refuerza la efectividad del preservativo masculino -para el que todavía existen barreras para su uso ${ }^{3}$ - como método tradicional de prevención de enfermedades de transmisión sexual (ETS), en este caso una con asociación probada al cáncer de cérvix.

Noelia Capellato [ Servicio de Medicina Familiar y Comunitaria del Hospital Italiano de Buenos Aires. noelia.capellato@ hospitalitaliano.org.ar ]

Capellato N. El uso del preservativo masculino reduce la el riesgo de transmisión genital del virus del papiloma humano en mujeres jóvenes. Evid Act Pract Ambul. 11(2) 36. Mar-Abr 2008. Comentado de: Winer R y col. Condom Use and the Risk of Genital Human Papillomavirus Infection in Young Women. N Engl J Med. 2006 Jun 22;354(25):2645-54. PMID: 16790697

Disponible libremente en URL: http://content.nejm.org/cgi/reprint/354/25/2645.pdf (último acceso 23/03/08).

\section{Referencia}

1. Shew M. Association of condom use, sexual behaviors, and sexually transmitted infections with the duration of genital human papillomavirus infection among adolescent women. Arch Pediatr Adolesc Med. 2006 Feb;160(2):151-6.

women. Arch Pediatr Adolesc Med. 2006 Feb;160(2):151-6.
2. Kjaer S. Risk factors for cervical neoplasia in Denmark. APMIS Suppl. 1998;80:1-41.

3. Basualdo N, Giraudo N, Discacciati V, Capellato N y López M. ¿Por qué cuesta usar el condón?: opiniones, creencias y conocimientos sobre el uso del preservativo en adultos de un suburbio de Buenos Aires. Archivos de Medicina Familiar y General Volumen 4 Número 2 - 2007

Disponible en URL: http://www.famfyg.org.ar/revista/revista_famfyg/volumen4_n2/05uso_condon.pdf (último acceso 15/01/08). 